\title{
公表調查データの統計解析による市街地ノンポイント 污濁負荷流出量の予測とその信頼性評価
}

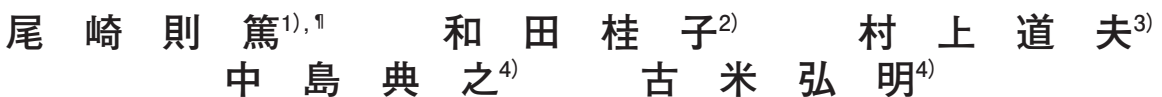

\section{Prediction and its Reliability Evaluation of Urban Non-point Pollution Loading by Statistical Analysis of the Data of Published Researches}

\author{
Noriatsu OZAKI I) , , Keiko WADA ${ }^{2)}$, Michio MURAKAMI ${ }^{3)}$, \\ Fumiyuki NAKAJIMA ${ }^{4)}$ and Hiroaki FURUMAI ${ }^{4)}$ \\ 1) Department of Civil and Environmental Engineering, Faculty of Engineering, Hiroshima University, 1-4-1 Kagamiyama, Higashihiroshima \\ 739-8527, Japan \\ 2) Institute of Lake Biwa-Yodo River Water Purification Research, Lake Biwa-Yodo River Water Quality Preservation Organization, Otemae 1-2-15, \\ Chuo-ku, Osaka 540-0008, Japan \\ 3) Fukushima Medical University, 1 Hikarigaoka, Fukushima 960-1295, Japan \\ 4) Graduate School of Engineering, The University of Tokyo, 7-3-1 Hongo, Bunkyo-ku, Tokyo 113-8656, Japan
}

\begin{abstract}
Papers and reports on investigations of the urban drainage in Japan were collected (1968-2011) and a database of urban runoff loading for each measured precipitation event was prepared. The targeted pollutants were BOD, COD, SS, $\mathrm{TN}$, and $\mathrm{TP}$, and their event mean concentrations (EMC) were included in each data set along with their precipitation event conditions. The distribution of loading and the geographic conditions of the basins were clarified, and the dependence of the EMC values on the precipitation and geographic conditions was modeled using the regression equation of a power law. Using this relation, the predicted yearly loading and coefficients of variation were derived for four representative precipitation conditions in Japan. The required sampling frequency to attain a certain accuracy of the annual loading was estimated by a simulation using the above model. From the results, at least half of the precipitation events must be sampled for the $95 \%$ confidence interval of annual loading to be within the range of half to double the true value.
\end{abstract}

Keywords: EMC (event mean concentration); Organic matter; SS; Nutrients; Specific load

\section{1.はじめに}

わが国では，公害問題の深刻化から，1970年に「水質 污濁に係る環境基準」(以下環境基準) が制定された。こ の環境基準を遵守するために，全国の公共用水域では， 排水規制の強化，生活排水対策の推進，下水道施設の整 備などの特定污染源（ポイントソース）に対する取り組 みが実施され，その結果，水質は改善し，河川の環境基 準の達成率は向上した。その一方, 湖沼や内湾, 内海な どの閉鎖性水域は, 集水域の人為的要因による栄養塩の 排出の増加に伴う富栄養化が進み, 異臭味や水道障害な ど水利用に支障をきたしている。このような閉鎖性水域 における環境基準の未達成には，水質污濁防止法の規制 等による流入污濁負荷の削減では対応できない多岐多様
な発生源の流入も関与している。とくに非特定污染源（ノ ンポイントソース）は，主に雨天時に広範囲にわたり流 出する面的な負荷源で，今なお十分な対策が取られてい るとは言いがたい。そのため，集水域の特定污染源に対 する施策の着実な実施とは対照的なノンポイントソース 対策の遅れによって, 流入污濁負荷源別の全負荷量に占 めるノンポイントソースの割合が増加していることが問 題視されている。なかでも, 市街地（道路・宅地）は, 人為的な污濁負荷発生の寄与が大きく，雨天時の流出水 には有機物や栄養塩類（窒素，リン）の他に，重金属類 や微量有害有機化合物, 病原微生物などの污染も報告さ れている ${ }^{(\sim 3)}$ 。一方で，水生生物の生息・生育にとって欠 かせない栄養塩類は，負荷量削減によって，一部の基準 達成水域では生態系や漁業生産への影響が顕在化してき

1) 広島大学大学院工学研究科 干739-8527 広島県東広島市鏡山 1-4-1

2 ）公益財団法人 琵琶湖・淀川水質保全機構 琵琶湖・淀川水質浄化研究所 † $540-0008$ 大阪市中央区大手前 1-2-15 大手前セン夕ービル 4F

3 ）福島県立医科大学 テ960-1295 福島県福島市光が丘 1

4 ) 東京大学大学院工学系研究科 干113-8656 東京都文京区本郷 7-3-1

ๆ連絡先 : ojaki@hiroshima-u.ac.jp 
たことから ${ }^{4,5)}$, 現在, 「豊かな海」,「水産資源の持続的 な利用の確保」を目指す新たな取り組みも始められてい る ${ }^{6.7)}$ 。したがって, 水利用用途やステークホルダーの要 望に応じて, 赤潮や貧酸素水塊, 病原性リスクなど従来 から継続する水質污濁問題への対策の推進や栄養塩類の 循環バランスによる生態系への配慮が必要となってきて いる。このような背景から, 水環境を管理する上でノン ポイント污濁負荷量の予測は必要不可欠であり, 適切な 影響因子を把握することはますます重要になってくると 考えられる。

水質保全のための污濁負荷量の現況把握と対策効果の 予測では, 現地モニタリングと, 污染の発生や流出に関 する機構解明とを組み合わせて行うが，ノンポイントソ 一スは地域特性に大きく影響され，また，流出負荷量の 時空間的な変動が大きいことから, 現況把握のための現 地モニタリングが重要と考えられている。しかし, 調査 の費用や時間等の制約から十分なデータを得られないこ とが多い。その場合, 現地デー夕に強く依存せず, 原単 位法や数值シミュレーションに基づき, 現況把握, 対策 効果の予測を行う方法もある。最近では, 雨水流出解析 ツールの進歩と GIS の整備により, モデル式による水質 の時空間的な変動を詳細に再現することも可能になって きた8)。このような現地モニタリングデータに強く依存 しない算定において重要になるのは用いたパラメータの 信頼度であり, とくに, 発生源における原単位は, 発生 する総負荷量を算定し, 大枠の発生量を把握する基礎デ ータとして重要視されているため, 流域別下水道整備総 合計画, 湖沼水質保全計画, 指針やガイドライン等で, 設定值の考え方や計算手法に基づき, 各土地利用形態や 水域別に提示されている ${ }^{9,10)}$ 。また, 原単位について調査 事例を総括している報告も見られる11 14)。これらのケー スでは，自然系のうち湖面降雨のように年次毎の測定が 可能な調査地点のデータを活用し, 基準年次に更新され るものもあるが, 宅地・道路をはじめ多様な土地利用形 態が混在する市街地は, 適用する地域の調査事例が少な いため，他の結果を基に設定されている場合がある。ま た, 1980〜1990 年代の調査結果が多く, 現在も適用可能 か疑問である。さらに，その後も各地域で調査が実施さ れてはいるものの, 標準的な推定手法がないため, 物質 収支の観点から数值の妥当性の検証までは至っていない のが現状である。

これらを鑑み, 日本水環境学会のノンポイント污染研 究委員会は, 環境研究総合推進費による研究課題として, 日本での原単位に係わる既往の文献について, 研究論文 および各自治体の調査報告書を含めた幅広い情報を収集 整理し, データベース（DB）の整備を行ってきた。ま た, ノンポイント污染源の位置づけや，原単位に関する 考え方について, 日本と海外での実情を踏まえた整理や, 市街地, 農地, 林地および森林で実際に提示されている 原単位について議論も行われた ${ }^{15,16)}$ 。

本報では，この DB 整備の成果に基づき，とくに市街 地を対象とし，基本項目である $\mathrm{BOD}, \mathrm{COD}, \mathrm{SS}, \mathrm{TN}, \mathrm{TP}$ について, 関係する文献や資料の再整理を行い, まずそ の集計した数值を報告した。本研究ではとくに重要な指 標として降雨ごとの EMC (流量加重平均濃度, event mean concentration）を抽出または算定した。続いてそ
の $\mathrm{EMC} に$ に影響を及ぼす諸因子を見いだし，それらとの 関係を定式化することを試みた。更にその式に基づき特 定の降雨状況が年間の污濁負荷流出量に及ぼす影響を考 察した。

また， 1 年間を通じてすべての降雨イベント（以下，イ ベントと記す）でデー夕を取得することは困難であり， 一般には限られた回数の調査から得られた合計負荷量お よび合計流出量と年間総流出量の比（あるいは合計降水 量と年間総降水量の比）から年間負荷量を推定する。し かし, 調査回数と年間負荷量の推定誤差の関係には不明 な点が多いことから, 年間負荷量を精度よく推定するた めの調査回数について解析を行った。

\section{2. 方法}

\section{1 データの入手と整理}

以下の方針に従い国内外の論文, 報告書等の文献を収 集した：

- 論文と, 官公庁, 国立や公立の研究機関等の報告書を 可能な限り網羅的に収集。

・日本を対象とした調查研究を収集。

結果として収集された論文 / 報告書件数は 163 本とな った（1968～2011, 報告書 : 37 件, 和文論文 : 71 本, 英 文論文 : 55 本)。なおこれらは 2015 年 1 月現在の情報で あり DB は今後も拡充される予定である。これらの各文 献を精読し観測 DBを作成した。観測 DB は基本的に「各 流域での一連の調査」をひとつのデータとし, 総計で 507 件となった。収集した文献の情報は日本水環境学会のノ ンポイント污染研究委員会のウェブページに掲載, 公表 している ${ }^{16)}$ 。図 S1 にデータの一例を示す。観測 DB が含 む内容は, 地点や流域に関する情報（地名や水系, 流域 面積など), 土地利用情報, 調査方法と時期, 対象物質, 得られた原単位などである。本報ではここから原単位等 にかかわる情報を抽出, 整理し, 代表值や影響因子を論 じる。

そのため, まず一降雨の調査の詳細が明らかとなって いる調查事例を観測 DB から抽出し, 改めて降雨調查 DB を構築した（文献数：13 本（表 S1 に文献リスト揭載）, デー夕数：111)。この降雨調査 DB は一イベントにつき 一データで構成される。イベントごとに抽出, 整理した 基本的な数值情報は, 排水面積, 人口密度, 年降水量, 調査日, 先行晴天日, 降雨量, 流出高, 流出率, EMC (BOD, COD, SS, TN, TP) である。ここで本研究では, $\mathrm{EMC}$ がノンポイント污濁負荷の最も主要な負荷量の指 標と考えた。EMC とはある流出地点での一イベントの 流量加重平均濃度で, 一イベントでの流出量 $\left(Q_{i}\right)$ と濃 度 $\left(C_{i}\right)$ がある時間間隔 $\left(\Delta t_{i}\right)$ で継続的に測定されてい る場合以下のように算定される：

$$
\mathrm{EMC} \equiv \frac{\sum_{i} C_{i} Q_{i} \Delta t_{i}}{\sum_{i} Q_{i} \Delta t_{i}}
$$

これらの数值情報は文献の本文中に直接示されていな い場合も多いが，本文から情報を論理的に読み取れる場 合は独自に算定した（例：人口密度を排水面積と域内人 口から算定, または EMC を濃度と流出量の経時変化か ら算定，など）。

EMCを指標とした考え方を説明する。原単位は $\mathrm{kg} \mathrm{ha}^{-1} \mathrm{yr}^{-1}$ で求めている事例も少なくないが, 論文によ 
って算定の方法論が異なるケースや，原単位として採用 するには必ずしも調査回数が十分ではないと懸念される ものもあった。また一方, 調査は実施しているが原単位 を算定していないものも多い。そこで一降雨の調査の詳 細が知られるものについて, その調査の詳細がデータべ ース化されることが望ましいという考えに至った。そこ で各降雨の調査を単位として DB 化し，その EMC を代 表的な結果として示すこととした。原単位の多くは EMC と年間降雨量から求められている。そのため本質的には $\mathrm{EMC}$ が元データであると考えられる。

\section{2 EMC の分布の特性の把握と予測}

$\mathrm{EMC}$ の分布の特性を把握した上で、それを踏まえて EMC に影響を及ぼす因子から EMC を予測する回帰式を 算定した。まず EMCの分布は正規分布と対数正規分布 へのあてはまりに関する検定をそれぞれ行い比較した。 検定にはPearsonの $\chi^{2}$ 検定を用い, 有意水準は $5 \%$ とし た。その結果いずれも正規分布にはあてはまらず対数正 規分布にあてはまった（各変量の分布を図 S2 に示す）。 EMCに及ぼす影響因子と EMC の予測では，EMCを目 的変数, 人口密度, 先行無降雨期間, 流出高, 時間最大 降雨強度を説明変数とした回帰分析を行った。回帰式と してはべき乗則を採用した (式 $(2))$ 。また得られた EMC の推定值の対数変換したものを $\mu$ とする（式（3））。回 縞は各変数をすべて対数変換したのちに重回帰分析を行 った。重回帰分析の適用に先立ち独立変数間の多重共線 性の影暜の有無を分散拡大係数（VIF）<10 を基準に判 定したところ, VIF の最大值は 2 程度であり, いずれの 変量も独立変数として採用できると考えた。変数減少法 により変数を選択し, 選択の基準を $\mathrm{F}$ 值 $>2$ とした。計 算には統計解析フリーソフト R 3.2.2 を用いた。

$$
\begin{aligned}
& \mathrm{EMC}=\alpha\left(\text { 人口密度 }{ }^{\beta} \times \text { 先行無降雨期間 }^{\nu}\right. \\
& \times \text { 流出高 }^{\delta} \times \text { 時間最大降雨強度 }^{\varepsilon} \text { ) }
\end{aligned}
$$

$$
\mu=\ln (\mathrm{EMC})
$$

ここで流出に影響を与える降雨強度の表現として時間 最大降雨強度を採用している。そのほかにも10 分最大降 雨強度, また流域の流出時間に合わせた時間を用いた表 現など様々にありうるが，デー夕の入手の容易さなどか らこちらを採用した。流出率を変数に採用していないが, この理由は流出高の中に流出率の情報が含まれていると 考えたためである。また降雨に関連する以外の因子は, 地理的情報では人口密度としてまとめた。影響パラメー 夕を設定する場合, 上記の他にも主要な因子が考えられ る。例えば, 宅地, 道路などの土地利用形態や, コンク リート，アスファルトなど表面工種も重要な影響因子で ある。これらも当初検討したが, 整理したデー夕の報告 書に示されていないものも多く採用に至らなかった。ま
た水質項目によっては西日本と東日本など地域で異なる 地質土壤を反映した違いが生じていることも推測された が, 解析には十分なデータではないと考え採用しなかった。

$2.3 \mathrm{EMC}$ の予測モデル式と降雨データに基づく年間 負荷量の予測

得られたモデル式および地理情報, 降水データに基づ いて，特定の流入域において年間降水パターンが生じた 場合の単位面積当たりの市街地からの流出負荷を推定し た。降水デー夕は地域気象観測システム AMeDAS の時 間值を用いた。

\section{4 調査回数による年間負荷量の推定精度のシミュレ ーションによる検討}

得られたモデル式に基づいて，1年のうちどの程度，ど のような降雨条件で採水をすると，年間負荷量をどの程 度の信頼度で得られるのかを予測した。そのため計算は 2014 年度東広島を対象として行った。予測モデル式に従 って算出された EMC デー夕と実際の気象デー夕を用い て負荷量・流出量データを仮想的にそろえた。イベント ごとの $\mathrm{EMC}$ は算術平均值と標準偏差にもとづいて対数 正規分布に従うと仮定して与えた。次に，1年間のイべ ントの内 (2014年東広島では全イベント数は 112 回), ラ ンダムに 1〜 50 回採取した場合の推定年間負荷量と実際 の年間負荷量（EMC データから用意された年間総負荷 量）の比を算出した。また先行晴天日数 3 日以上かつ降 水量 $2.5 \mathrm{~mm}$ 以上のデータという条件で（2014 年東広島 では 24 回）ランダムに 1〜24 回採取した場合の比につい ても算出した。ここで推定年間負荷量はサンプリング対 象イベントの合計負荷量に調査対象イベントの合計流出 量に対する年間総流出量の比を乗じることによって算出 した。計算は, 数值シミュレーションソフト Crystal Ball (Oracle 社) を用いた 100000 回のモンテカルロシミュレ ーションによって行った。

\section{3. 解析結果と考察}

3. 1 データ及び重要な諸元の指標値の範囲および特性

まず, 得られた DB の調査情報について, 筆者らが最 も主要と考えた数值的な諸元とその範囲を示す（表 1)。 ただし調査結果として示すべき情報はこれらで十分と考 えるわけではなく, 十分な諸元の内容は図 S1 の内容と 考える。得られた総デー夕数は前述の通り 111 であり, 一方対象となった流域数は 33 である（ひとつの流域で複 数回測定している場合は別のデータとしている)。調査時 期は 1988～2008年であった。また本研究では，解析を行 うにあたり図 S1 に含まれていない内容として時間最大 降雨強度を追加している。降雨強度が負荷流出に影響を 与えると考えたためである。

続いて BOD, COD, SS, TN, TP の EMC の集計值を表 2, 図 1 に示す。 $25 \%$ 值〜 $75 \%$ 值は数倍の範囲に収まっ

表 1 データベースに含まれる降雨の諸元の範囲

\begin{tabular}{cccccccc}
\hline & $\begin{array}{c}\text { 排水面積 } \\
(\mathrm{ha})\end{array}$ & $\begin{array}{c}\text { 人口密度 } \\
\left(\text { ( h } \mathrm{ha}^{-1}\right)\end{array}$ & $\begin{array}{c}\text { 降雨量 } \\
\left(\mathrm{mm} \mathrm{event}^{-1}\right)\end{array}$ & $\begin{array}{c}\text { 先行無降雨期間 } \\
(\text { day })\end{array}$ & $\begin{array}{c}\text { 流出高 } \\
\left(\mathrm{mm} \mathrm{event}^{-1}\right)\end{array}$ & $\begin{array}{c}\text { 時間最大降雨強度 } \\
\left(\mathrm{mm} \mathrm{hr}^{-1}\right)\end{array}$ & $\begin{array}{c}\text { 流出率 } \\
(-)\end{array}$ \\
\hline データ数 & 108 & 60 & 111 & 108 & 107 & 108 & 110 \\
平均值 & 111.98 & 71.33 & 15.58 & 7.17 & 5.83 & 4.29 & 0.41 \\
25\%値〜75\%値 & $8.2 \sim 67$ & $30.49 \sim 106.27$ & $6.5 \sim 17$ & $2.35 \sim 6.69$ & $1.6 \sim 8.05$ & $2 \sim 6$ & $0.19 \sim 0.49$ \\
最小值〜最大值 & $0.89 \sim 3698$ & $16.29 \sim 168.54$ & $1 \sim 72.5$ & $0.42 \sim 63$ & $0.16 \sim 31.88$ & $0.5 \sim 18.5$ & $0.04 \sim 3.46$ \\
\hline
\end{tabular}


表 2 各水質項目の $\mathrm{EMC} の$ 範囲

\begin{tabular}{cccccc}
\hline $\mathrm{mg} \mathrm{L}^{-1}$ & $\mathrm{BOD}$ & $\mathrm{COD}$ & $\mathrm{SS}$ & $\mathrm{TN}$ & $\mathrm{TP}$ \\
\hline データ数 & 26 & 102 & 83 & 73 & 73 \\
平均值 & 7.87 & 11.62 & 55.0 & 2.26 & 0.154 \\
中央值 & 5.55 & 9.12 & 39.8 & 2.10 & 0.120 \\
幾何平均値 & 6.07 & 9.64 & 34.9 & 1.84 & 0.120 \\
25\%値〜75\%値 & $3.43 \sim 11$ & $5.98 \sim 15.23$ & $18.4 \sim 70.3$ & $1.2 \sim 2.9$ & $0.073 \sim 0.22$ \\
CV値 (\%) & 76 & 64 & 100 & 64 & 69 \\
\hline
\end{tabular}

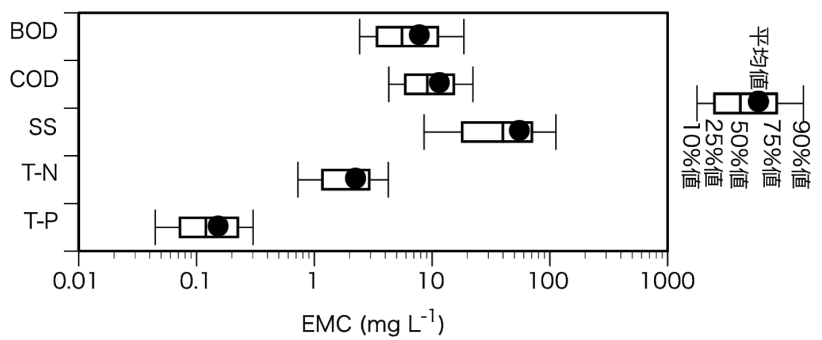

図 1 各水質項目の $\mathrm{EMC}$
表 3 各水質項目の相関（相関係数）

\begin{tabular}{llllll}
\hline $\mathrm{R}$ & $\mathrm{BOD}$ & $\mathrm{COD}$ & $\mathrm{SS}$ & $\mathrm{TN}$ & $\mathrm{TP}$ \\
\hline $\mathrm{BOD}$ & - & & & & \\
$\mathrm{COD}$ & $0.92 *$ & - & & & \\
$\mathrm{SS}$ & 0.16 & $0.64 *$ & - & & \\
$\mathrm{TN}$ & $0.72 *$ & $0.53 *$ & 0.16 & - & \\
$\mathrm{TP}$ & $0.73 *$ & $0.76 *$ & $0.63 *$ & $0.54 *$ & - \\
\hline
\end{tabular}

有意確率 $<0.05$

表 $4 \mathrm{EMC}$ の予測式（本文の式 (2)）のパラメータおよび予測式の精度

\begin{tabular}{|c|c|c|c|c|c|c|c|c|}
\hline & $a$ & $\begin{array}{c}\beta \\
\text { 人口密度 } \\
\left(\text { 人 ha }{ }^{-1}\right)\end{array}$ & $\begin{array}{c}Y \\
\text { 先行 } \\
\text { 無降雨期間 } \\
\text { (day) }\end{array}$ & $\begin{array}{c}\delta \\
\text { 流出高 } \\
\left(\mathrm{mm} \mathrm{event}^{-1}\right)\end{array}$ & $\begin{array}{c}\varepsilon \\
\text { 時間最大 } \\
\text { 降雨強度 } \\
\left(\mathrm{mm} \mathrm{hr}{ }^{-1}\right)\end{array}$ & $R^{2}$ & $\sigma$ & $P$ \\
\hline COD & 1.28 & 0.118 & 0.622 & - & 0.284 & 0.40 & 0.433 & $<1 \times 10^{-4}$ \\
\hline SS & 19.6 & - & - & - & 0.474 & 0.15 & 0.967 & $2 \times 10^{-4}$ \\
\hline $\mathrm{TN}$ & 0.971 & - & 0.385 & - & - & 0.22 & 0.598 & $<1 \times 10^{-4}$ \\
\hline $\mathrm{TP}$ & 0.0497 & - & 0.398 & 0.172 & - & 0.19 & 0.678 & $6 \times 10^{-4}$ \\
\hline
\end{tabular}

- (ハイフン) は検定の結果採用されなかったパラメータ

$\left(a, \beta, \gamma, \delta, \varepsilon\right.$ : 予測式 (式 (2)) のパラメータ, $R^{2}$ : 予測式の決定係数, $\sigma$ : 予測式を基準にしたデータの標準偏差, $P$ : 有意確率)

ている。代表値として (算術) 平均值, 中央值, 幾何平 均值，25\%值〜 $75 \%$ 值を示した。また分布は前述の通り おおむね対数正規分布に従っていた。

3. 2 EMC に及ぼす影響因子と EMC の予測

本報告の数值を用いて流域の年間負荷量を算定する場 合，最も単純な方法として得られた各 $\mathrm{EMC}$ の平均值に 年間降雨量と平均流出率と流域面積を乗じるというやり 方がある。一方，ある程度の地理情報と降雨情報が得ら れる場合，その情報に基づき各降雨の $\mathrm{EMC} の$ 予測值の 範囲を絞り达むことで，積算される年間負荷量の精度を あげることが考えられる。そこで EMC の諸元に対する 依存性の有無と関係性の定式化について考察した。

まず，水質項目同士の相関を検討した（項目同士の散 布図を図 S3 に示す)。そのため水質項目同士の相関係数 を計算した（表 3)。BOD-COD 間は高い相関が見いださ れた。SSとBOD またはTNなどは相関が低かった。 BOD, COD, TN, TP はお互いに類似しており SS はそれらと類 似性が低い傾向にあるといえる。

続いて人口密度, 先行無降雨期間, 流出高, 時間最大降 雨強度と $\mathrm{EMC}$ との相関の有無を検討し，回帰式を求め た。ただし BOD は重回帰分析を行うには十分なデータ
数ではないと考え（デー夕数 26 ; 表 2), 分析対象から除 外した。BOD の EMC は COD と高い相関であったこと から (表 3)，引き続く解析においてもCOD の解析で得 られた傾向が BOD にもあてはまると考えている（なお $\mathrm{BOD}$ と $\mathrm{COD}$ の関係は $\mathrm{BOD}\left(\mathrm{mg} \mathrm{L}^{-1}\right)=0.76 \times \mathrm{COD}$ $\left(\mathrm{mg} \mathrm{L}^{-1}\right)-1.9$ であった; $\left.R^{2}=0.84\right)$ 。各水質項目に関す る式 (2) の独立変数として採用された変数とその係数お よび $R^{2}, \sigma, P$ 值を表 4 に示す。回帰分析に際しては変 量を対数化した值に対して行ったため, 得られた $R^{2}, \sigma$ は対数化した值に対しての決定係数と回帰直線を基準に したデー夕の標準偏差である。 $P$ 值よりいずれも有意な 相関であった。いずれもすべての変数ではなく 1 つから 3 つの変数が独立変数として選択された。独立変数のう ち人口密度のみが地理的な条件であるが，CODのみ人口 密度との相関が見いだされた。また図 2 に予測值と実測 值の值を示す。予測值と実測值は誤差最大 10 倍程度 (SS) で予測值の増加とともに実測值も増加する傾向にある。 COD はある程度良好に見えるが，SSはばらつきも大きい。

各変量に対する依存性を記述するモデルとしては Sartor \& Boyd による定式化 ${ }^{17)}$ や中村による方法 ${ }^{18)}$ など がある。本研究でもそれらの物理モデルの適用がより望 
ましいと考えたが, これらのモデルに必須のパラメータ である流出高が重回帰分析で TP 以外は相関があるとは 判断されなかったこと, また異なる流域でのデー夕の寄 せ集めに, 経時変化のモデルをあてはめることは無理が あると考えたことから，採用しなかった。

ここで得られた関係式は, パラメータの選択そのもの は物理的な過程を考慮したものであるが, 簡単な相関関 係に基づく統計モデルであり, EMCの予測值としての 適用にあたっては慎重さが求められる。さまざまな流域 に適用しようとする場合, その流域における表 1 の值は $25 \%$ 值〜 $75 \%$ 值か, 少なくとも最小值〜最大值の範囲に 収まっていることが条件になると考えられる。

3.3 予測式の適用に関するケーススタディ

ここまでの解析では人口密度という流入域の地理情報 を含めて行ったが。結果的に, COD が人口密度に依存し たことを除いては降雨にかかわるパラメー夕のみが有意 な予測パラメータとして残った。そこで降雨情報を重視 し, 日本における典型的な降雨パターンが与えられた際 のモデル值の応答性について解析した。日本全国の複数 の地点の降雨情報から, 前記の式 (2) を用いて EMC お よび年間流出負荷量を算出し変動特性について検討した。 まず，複数の地点の AMeDAS から得られた時間降雨量 から, 表 4 に示した回帰係数を与えた EMC 算定式を用 いて年間流出負荷量を求めた。算定に際しての主要な仮 定は以下の通り：

- 年間流出量は各一降雨の EMC と流出高の積の, 年間 の合計值とした。

・ EMC は場所によらず前記の EMC 算定式に従うものと した。

-一降雨の流出高は一降雨の降雨量と流出率の積とした。 ただしここでは流出率は DB の平均值（0.41；表 1 参照） を用いた。
・COD は流入域の人口密度に依存する結果であったが, 計算に際しては DB の平均值 (71.33 人 $/ \mathrm{ha}$; 表 1 参照) を用いた。

・一降雨は一続きの連続した降雨として定義した。時間 降雨量データにもとづき無降雨間隔が 6 時間以内の場合 その前後は降雨が連続していると見なした ${ }^{19)}$ 。

なお雨量デー夕は降雪を含んでおり，降雪による負荷 は本研究のモデルからは外れるため別途検討するべきで あるが，ここでは簡単のためにすべて降雨として区別せ ずに取り扱っている。一般的な日本の気候区分 ${ }^{20,21)}$ を参 考にし，各気候区分から選ばれるように，また，ノンポ イント污染の調査実施例が多いところと近いような地点, という観点を含めて検討した。ただし降雪が多い気候区 分は対象から外して選択した。選択した地点は千葉，東 広島, 鹿児島, 那覇（すべてアメダス観測地点）である。 計算期間は 2010 年 1 月 1 日〜 2014 年 12 月 31 日の 5 年 間とした。各地点の期間中の降雨状況は表 5 に示すとお りである。

計算の手順を以下に示す。計算に先立ち AMeDAS の 一時間毎の連続降雨データからイベント毎の一回降雨量, 流出高（降雨量に一定の流出率（0.41）を乗じた), 先行 無降雨期間, 時間最大降雨強度を導出し, それらの連続 したデータを得た。続いて以下のように計算した：

(1) 各降雨の $\mathrm{EMC}$ の対数平均值（式（3）の $\mu$ ）および 対数標準偏差（表 4 の $\sigma$ ）を導出した。

(2) 各降雨の $\mathrm{EMC} の$ 算術平均值および算術標準偏差を 以下の (4)，（5）式より求めた。長期的な負荷量の積算 值や平均值を算定するための集約值としては対数平均值 ではなく算術平均值が基本と考えたためである。

$$
\text { 各降雨の } \mathrm{EMC} \text { の算術平均值 }=\exp \left(\mu+\frac{\sigma^{2}}{2}\right)
$$
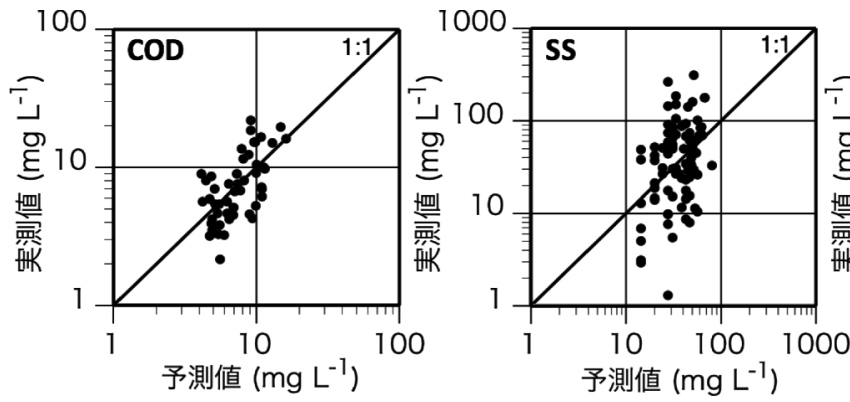

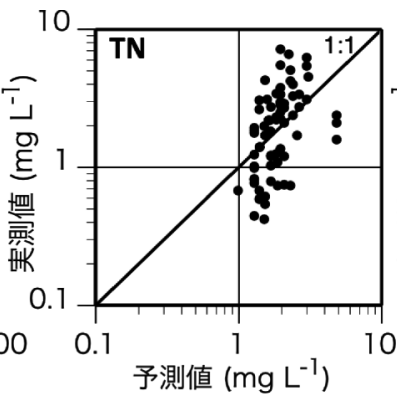

予測值 $\left(\mathrm{mg} \mathrm{L}^{-1}\right)$

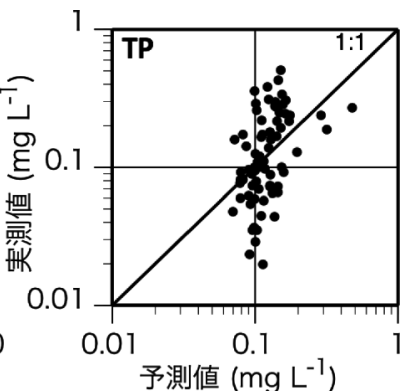

図 2 各水質項目の $\mathrm{EMC}$ の予測值と実測值

表 5 対象降雨の諸元（2010-2014 年）

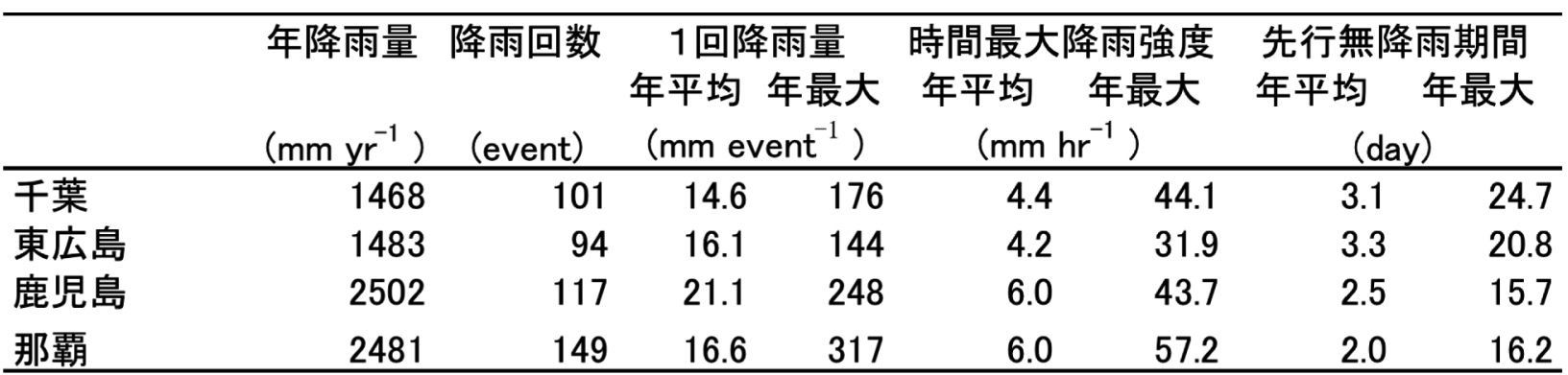

値はいずれも年間代表値(平均値, 最大値)の5年平均値 
各降雨の $\mathrm{EMC} の$

算術標準偏差 $=\sqrt{\exp \left(2 \mu+\sigma^{2}\right)\left\{\exp \left(\sigma^{2}\right)-1\right\}}$

(3) 年間負荷量の期待值および標準偏差を以下のように 算出した。まず年間負荷量の期待值について（6）式より 各降雨の流出負荷量を導出し, 得られた流出負荷量の值 の年間の合計を年間負荷量の期待値とした：

$$
\begin{aligned}
\text { 各降雨の流出負荷量 }= & (\text { 各降雨の流出高 }) \times(\text { 各降雨の } \\
& \mathrm{EMC} \text { の算術平均值 }) \quad(6)
\end{aligned}
$$

年間負荷量の標準偏差については, 以下の（7）式より各 降雨の流出負荷量を導出し, 更に（8）式により流出負荷 量の標準偏差を導出した：

\section{各降雨の流出負荷量の}

標準偏差 $=($ 各降雨の流出高 $) \times($ 各降雨の $\mathrm{EMC}$ の算術 標準偏差)

年間の流出負荷量の標準偏差 $=$

$$
\sqrt{\sum_{\text {年間 }}(\text { 各降雨の流出負荷量の標準偏差 })^{2}}
$$

以上のすべての計算例はインターネット上のファイル で示している (URL: http://home.hiroshima-u.ac.jp/ ojaki/SI2.xlsx)。本研究では実測值から予測式を導出し, それに基づき上記の手順で年間負荷量の標準偏差を算定 した。ただし本研究で採用した年間負荷量の標準偏差の 算定方法は厳密なものではなく簡略化した方法とした（テ キストS1)。以下の計算は各降雨の流出負荷量が表 4 の 関係に従うと仮定している。

年間負荷量の例を表 6 に示す（表 S2 に全地点, 全年

表 6 東広島を例とした污濁物質の年間負荷量の例 (2014年)

\begin{tabular}{ccc}
\hline & $\begin{array}{c}\text { 年間負荷量 }^{{ }^{* 1}} \\
\left(\mathrm{~kg} \mathrm{ha}^{-1} \mathrm{yr}^{-1}\right)\end{array}$ & $\begin{array}{c}\text { 変動係数 } \\
(\%)\end{array}$ \\
\hline $\mathrm{COD}$ & $40.5 \pm 3.8$ & 9 \\
$\mathrm{SS}$ & $507 \pm 142$ & 28 \\
$\mathrm{TN}$ & $9.1 \pm 1.1$ & 12 \\
$\mathrm{TP}$ & $0.76 \pm 0.11$ & 15 \\
\hline
\end{tabular}

*1 数値は平均值士標準偏差, *2 数值は（標準偏差 / 平均値)
の結果を示す)。得られた標準偏差はモデルによる予測誤 差と解釈できる。東広島の例では年間負荷量の予測值の 変動係数は $9 \%$ ～28\%であった。図 2 に示されたように、 予測值と実測值との関係が大きくばらついているにもか かわらず、変動係数は比較的小さかった。なお表 6 の結 果自体は特定の地域, 年に限った結果であるが, 他の地 点, 年も変動が抑えられているという点で同様の傾向で あった。予測值のばらつきが大きい回帰式を用いている にもかかわらず変動係数が小さくなる計算上の理由は, 各降雨のばらつきが独立に生じると見なして年間の標準 偏差を算定しているためである。降雨ごとの偏差が独立 に生じるのであれば，たとえば 100 回の降雨の合計值の 変動係数は $\frac{1}{\sqrt{100}}$ に減る計算になる。また, ここでの計算 は流出率の変動は含まれていない点にも留意するべきで ある。

次に, 計算結果の評価に先立ち計算に用いた個別の降 雨の条件が，先に得られた DB の範囲にどの程度収まっ ているのかを検討した。そのため各降雨の諸元の範囲を 表 1 と比較した。比較のため重要な諸元は降雨量, 時間 最大降雨強度，先行無降雨期間と考えた。ただし比較す る範囲の項目は最大值のみとした。最小值を対象としな かったのは, 降雨量, 時間最大降雨強度については, そ れらの最小值が小さい降雨の, 全体への影響は小さいと 考えたためであり，先行無降雨期間はあらかじめ 6 時間 より短い降雨は一連の降雨と見なしているため更なる制 限は不要と考えたためである。結果を図 3 に示す。

各降雨について範囲を超えた項目はすべて降雨量また は時間最大降雨強度であり, 先行無降雨期間が範囲を超 えていた降雨はなかった。実質的にはある程度以上の強 い降雨の実データが欠けているということになる。全体 により南の方が DB 範囲外の降雨量または流出負荷量が 多い傾向にある。DB 範囲外の寄与が大きい鹿児島や那 覇について, 年ごとの変動を見たところ, 年ごとに変動 する大部分が DB 範囲外の降雨により生じている傾向が 確認できた。DBの範囲を超える降雨は降雨の頻度とし ては大きくはなかったが (鹿児島, 那覇であっても発生 頻度は $10 \%$ 程度であった), それらは強い降雨であり, 計 算上は強い降雨が変動成分を担っていると解釈される。
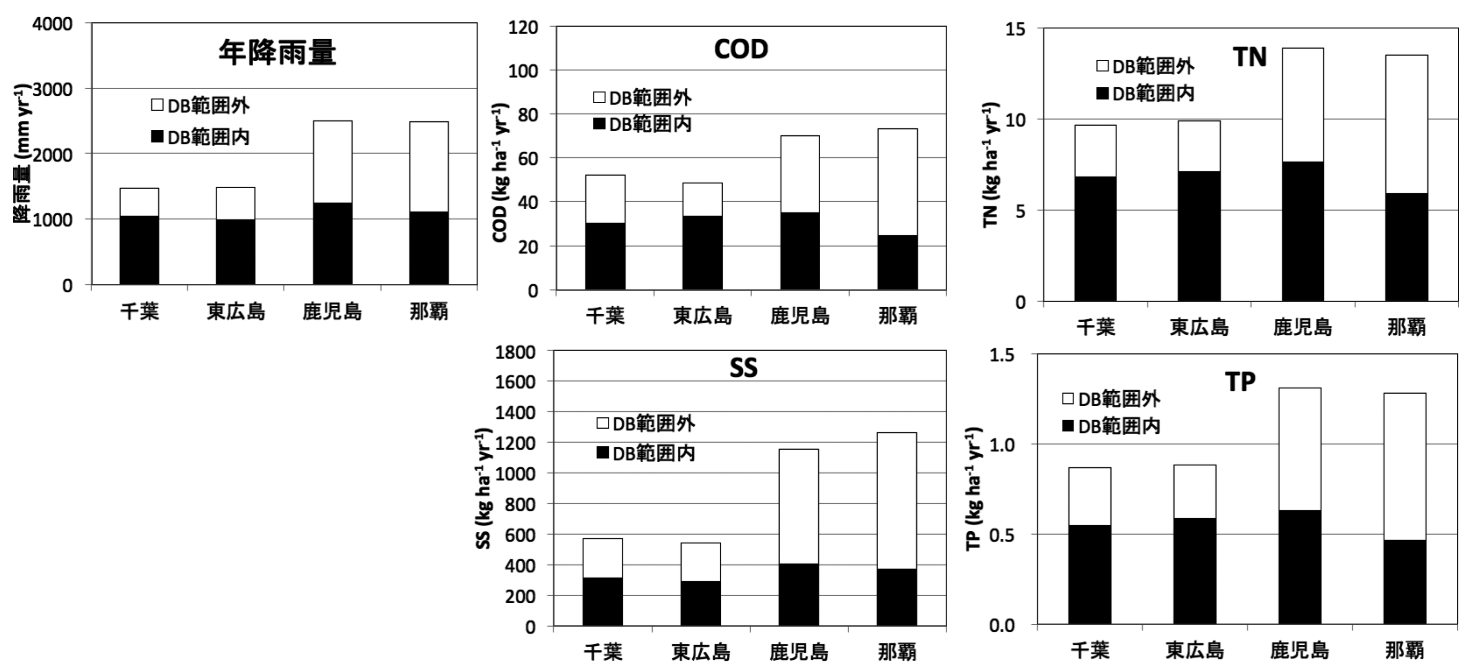

図 3 各地点の各降雨において本研究で用いた DB の範囲（表 1 の降雨に関する条件）を超えている降雨による負荷の総量（DB範 囲外）と総流出負荷量（DB 範囲外 $+D B$ 範囲内）（2010-2014 年の平均） 
鹿児島や那覇など降雨が強い地点では絶対的な割合も過 半であり, 重要な寄与を占めている。つまり平均的な傾 向についてはこれまで得られている調査結果に基づいた 議論になるが, 地域毎や年ごとの変動を議論することは 調査を踏まえた実証的な議論を外れていることになる。 限られたデータからできるだけの議論をして現時点での 最善の暫定的な判断を得るという状況では, 本研究での 議論は一定の有効性をもつと考えられるが, 今後は強い 降雨での流出をより確実に把握し実証的な裏付けを得る ことが重要である。またこういった年間の合計の負荷量 を推定することを本計算によって実施する際には，この ような範囲に含まれないような降雨の頻度とその計算上 の負荷量はあらかじめ把握した上, 最終的な判断は現場 の状況の理解を踏まえて行われる必要があろう。

次に, 計算をすべての地点, 年について実施した結果 を図 4 と表 7 に示す。図 4 を見ると年降雨量と時間最大 高強度については, いずれも増加するにつれて負荷量も 増加する傾向にある。TN, TP は時間最大降雨強度が予

表 7 全地域 (千葉, 東広島, 鹿児島, 那覇), 年 (2010-2014 年）の污濁物質の年間負荷量の平均（デー夕数は各 20 $(4 \times 5))$

\begin{tabular}{ccc}
\hline & $\begin{array}{c}\text { 年間負荷量 } \\
\left(\mathrm{kg} \mathrm{ha}^{-1} \mathrm{yr}^{-1}\right)\end{array}$ & $\begin{array}{c}\text { 変動係数 }{ }^{* 2} \\
(\%)\end{array}$ \\
\hline COD & $61.0 \pm 17.9$ & 29 \\
SS & $885 \pm 377$ & 43 \\
TN & $11.8 \pm 2.8$ & 24 \\
TP & $1.07 \pm 0.30$ & 28 \\
\hline
\end{tabular}

*1 数値は平均值士標準偏差, *2 数值は（標準偏差 / 平均値）
測式に入っていないにもかかわらず時間最大降雨強度と 高い相関を示している。これは年降雨量が高い地点では 時間最大降雨強度も高い傾向があったためである。一方, 先行無降雨期間については明確な相関は見られない。全 体として, いずれも日本の気候の範囲では降雨パターン によらず降雨量や降雨強度が増えると流出負荷も増える と考えられる。

\section{$3.4 \mathrm{EMC}$ の変動が年間負荷量に及ぼす変動の範囲の 再検討}

前節では東広島を事例として年間負荷量とその変動係 数を計算した（表 6)。この変動係数はもともとの予測值 と実測值のばらつきと比べて小さいように思われたが, その理由は前節でも述べたように，EMCの予測值から の変動が降雨ごとに独立に発生すると見なしたこと，流 出率の変動を含んでいないことが考えられた。このうち, とくに独立性について考察する。本モデルで得られたば らつきは，実際には降雨ごとに独立であるとは限らない。 例えば，降雨ではなく，流域毎に決まる因子のみが変動 の原因であったと仮定する。その場合, 同じ流域で複数 の降雨の $\mathrm{EMC}$ を予測して負荷を算出する上で, 変動が 降雨ごとに相殺されることはない。そこで, 現在得られ ている予測のばらつきは, 流域を特徽付ける因子のみに よって決まると考える（因子名をXとする）。Xはすで に本研究で採用している因子（人口密度（表 4)）とは相 関しないとすると, Xに起因する変動はランダムなばら つきとして観察される。同じ流域内であればXは同一で あるため変動も降雨毎に同じになる。この場合, 年間負 荷量の変動係数は一降雨ごとの $\mathrm{EMC}$ 予測值の変動係数 と同一になり，変動係数は水質項目ごとに $45 \%$ ～124\%
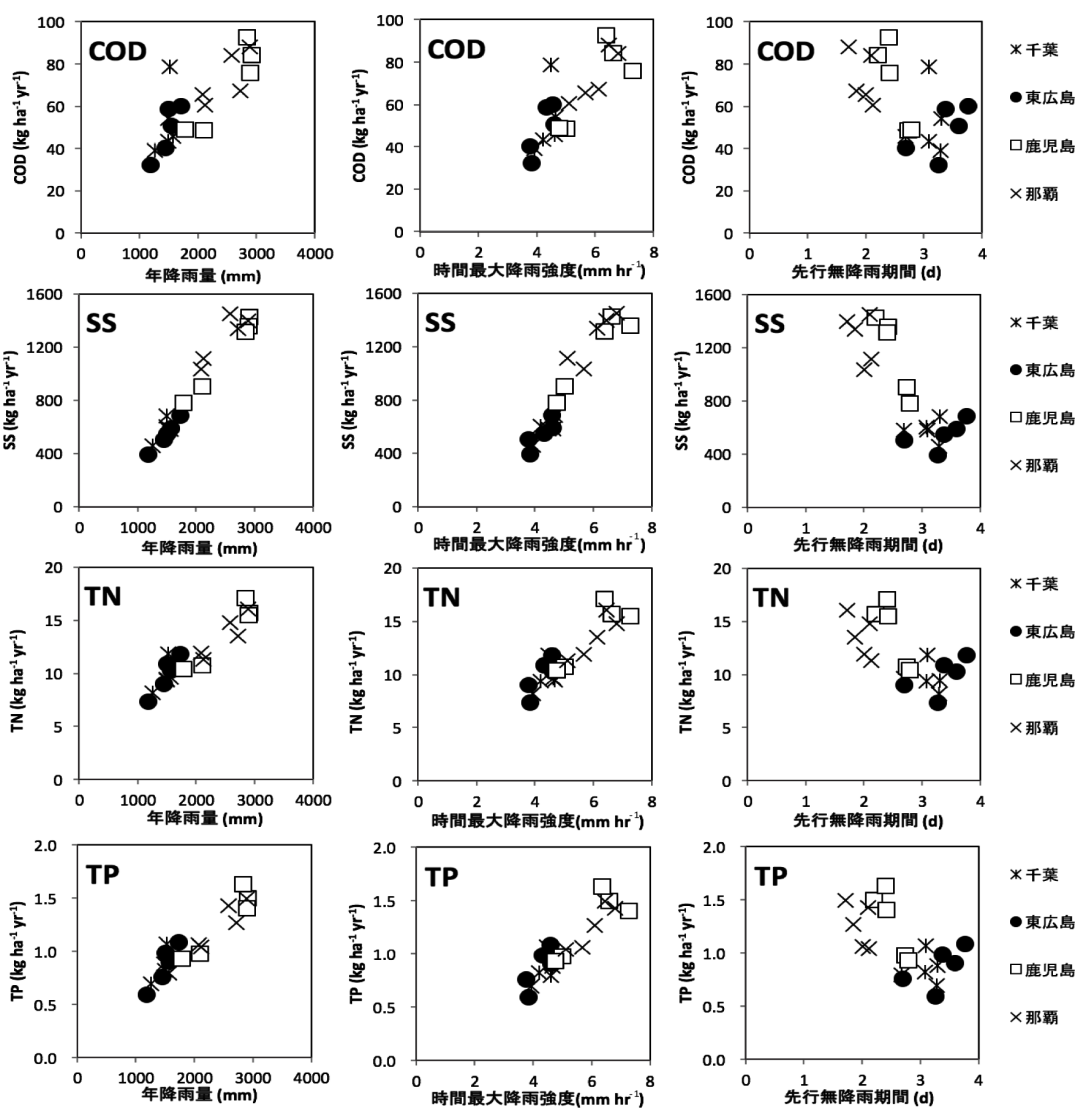

図 4 降雨パターンとモデルから導出された各地域の年間負荷量（2010-2014 年の各年） (時間最大降雨強度と先行無降雨期間は各地点においてそれぞれの降雨の年平均値で示した.) 
と計算される。これは表 6 の值より大きい。実際には $\mathrm{EMC}$ のばらつきが全て流域ごとの違いに起因するとは 考えられず, むしろ変動要因の大部分が, 降雨条件に依 存していると考えるほうが自然であろう（これは表 6 の 仮定の考え方である)。しかしそのことを実証的に検討し てはおらず，本研究では捉えられていない少数の支配的 な因子が大きく影響を及ぼして, 測定ごとの相関に強く 影響を及ぼしている可能性も否定できない。すなわち, 表 6 の変動係数の值は過小評価されており, この点の検 討も今後の課題である。

\section{5 調査回数が年間負荷量の推定に及ぼす影響}

本モデル式に基づき，現場で限られた回数の調査を実 施しそこで得られた EMC から年間負荷量を推定する場 合の, 推定值の変動特性をシミュレーションにより求め た。本シミュレーションは東広島の 2014 年の降雨および 流出負荷量のパターンを例として計算した。ここでは, 各降雨の負荷変動が独立であると見なして解析した。調 査実施の判断に関して先行晴天日数 3 日以上かつ降水量 $2.5 \mathrm{~mm}$ 以上という条件を設けた場合と, 条件なしの場 合とで推定された年間負荷量と実際の年間総負荷量 (EMCデータから計算された年間総負荷量) の比を取っ た（図 5)。調査の回数が多くなるにつれてばらつきが小 さくなり，また同じ調査回数では条件ありの方が概して ばらつきが小さくなった。SSのばらつきが大きく COD のばらつきが小さかったが，これは各項目の年間負荷量 の変動係数の大小関係 (表6) と同様の傾向であった。条 件ありでは調査回数が多くなっても中央值は 1 には近づ かなかった。これは, すべての降雨イベントの母集団か ら採取しているのではなく, 降水量や先行晴天時間が一 定以上のイベントのみで試料採取するという, 調査方法 によるものである。

ここで仮に「 $25 \%$ タイル值・ $75 \%$ タイル值が 2 倍以内 （すなわち， $50 \%$ の確率で 2 倍以内）を満たす調査回数」 を, 年間負荷量を精度よく推定するための最低限必要な 調査回数と想定すると, 条件なしでは COD, SS, TN, TP

の順に 4，10，2，5回だったのに対し，条件ありでは 1 , 6, 1，1 回であった（表 8)。すなわちすべての項目につ いて $50 \%$ の確率で 2 倍以内の誤差となるように年間負荷 量を推定したいのであれば, 先行晴天日数 3 日以上かつ 降水量 $2.5 \mathrm{~mm}$ 以上のイベントならば 6 回以上, 任意の イベントであれば 10 回以上の降雨調査が必要となる。こ れに対し, 解析対象の 2014 年広島では, 1 か月あたり約 9 回のイベントがあった（1 年間で 112 回）。このことか ら, 調査によって得られた $\mathrm{EMC}$, 対象イベントの総流 量, 年間総流量のデータを用いて $50 \%$ の確率で 2 倍以内 の誤差となるように年間負荷量を推定するためには，約 1 か月のすべてのイベントでの調査が必要であることが 示唆された。

一方, 「2.5\%タイル值・97.5\%夕イル值が 2 倍以内」(95 $\%$ の確率で 2 倍以内）を，年間負荷量を精度よく推定す るために必要なサンプリング回数と想定した場合, 条件 なしでは COD, SS, TN, TP の順に 21，48，15，22 回だ ったのに対し, 条件ありでは 18, not available (24 回す べてのイベントを採取しても 2 倍以内に収まらない)。15, 19 回であった。これはすべての項目で $95 \%$ の確率で 2 倍 以内の誤差となるように年間負荷量を推定するためには, 1 年間のうち半分近くのイベントでの調查が必要である ことを示している。すなわち, 仮に 1 年間の約半分のイ ベントでのサンプリング調査に基づいて年間負荷量を算 定した場合でも，95\%信頼区間での変動の大きさが 2 倍 程度生じることを踏まえた上で, 実態把握や対策立案と

表 8 污濁物質の年間負荷量の算定にあたり一定程度以上の精 度を得るための必要サンプリング回数 (東広島, 2014 年)

\begin{tabular}{|c|c|c|c|c|}
\hline & \multicolumn{2}{|c|}{$\begin{array}{c}25 \% \text { タイル値· } 75 \% \text { タイル値が } \\
\text { 2倍以内 }\end{array}$} & \multicolumn{2}{|c|}{$\begin{array}{c}\text { 2.5\%タイル値·97.5\%タイル值 } \\
\text { が2倍以内 }\end{array}$} \\
\hline & 条件なし & 条件あり & 条件なし & 条件あり \\
\hline COD & 4 & 1 & 21 & 18 \\
\hline SS & 10 & 6 & 48 & not available \\
\hline TN & 2 & 1 & 15 & 15 \\
\hline TP & 5 & 1 & 22 & 19 \\
\hline
\end{tabular}
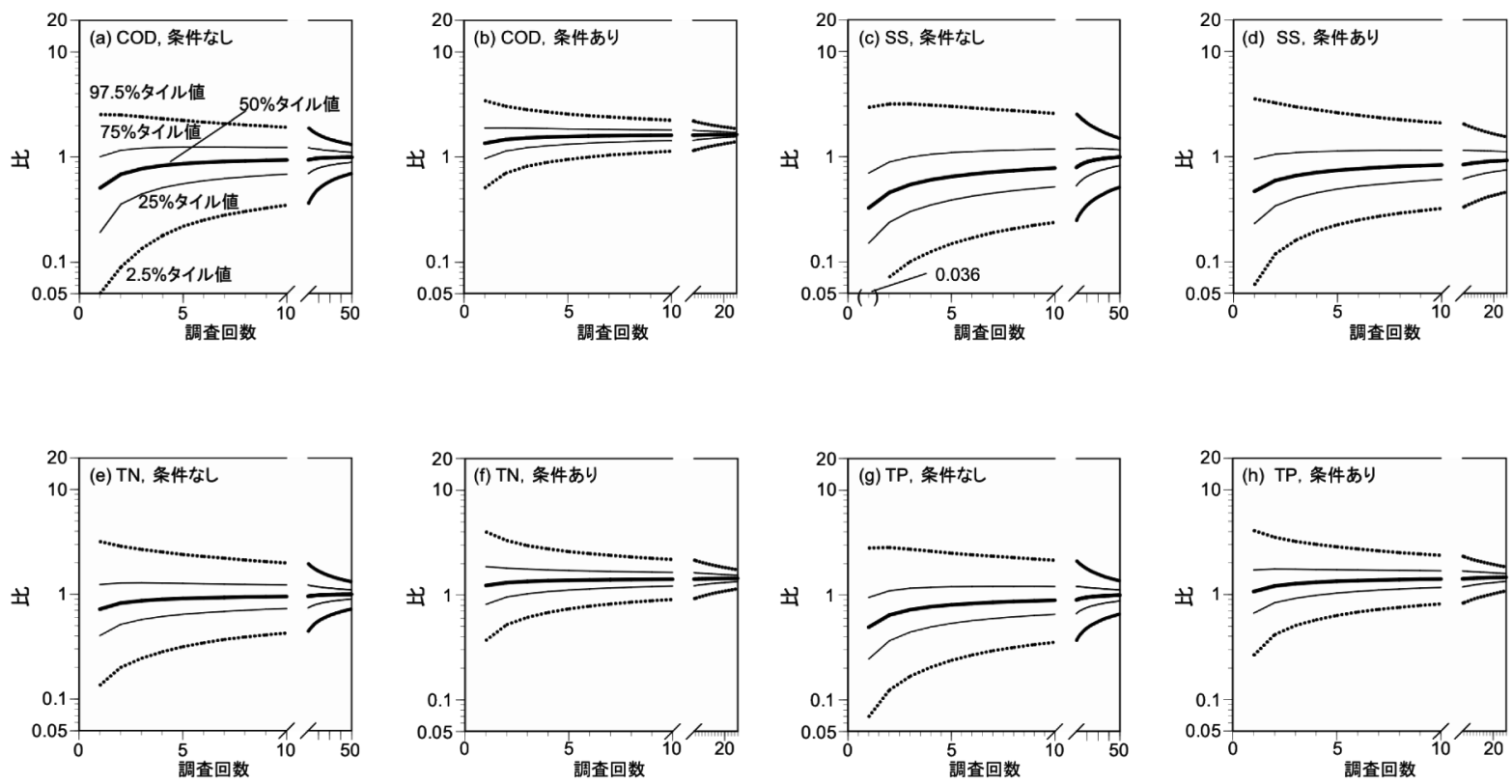

図 5 限られた回数の調査から推定された年間負荷量と年間総負荷量の比（モデルから算定された各降雨負荷量を用いて実施した シミュレーション結果；東広島, 2014 年) 
いった評価を行わなければならない。またこの解析は対 象地域と対象年を固定した上での結果である。対象地域 が異なる場合や，同一地域でも気象条件の異なる年の年 間負荷量を推定するのであれば, さらに異なる変動要因 が生じることに注意が必要である。

\section{4. まとめと今後の展望}

（1）人口密度，先行無降雨期間，流出高，時間最大降 雨強度を変数とし, 年間流出負荷の予測值とその変動係 数を算出する方法を検討した。またそれに基づき日本全 国で複数の地点で降雨量の経時変化に基づき単位面積当 たりの污濁流出負荷量を算定した。今後地域的, 長期的 な傾向を議論するための基礎になり得ると考えている。 一方, 変動要因の考察に基づき本研究で得られた変動倸 数はモデルの仮定によって大きく異なる可能性も示唆さ れた。この点は今後の検討課題と考えられる。また得ら れたモデル式の妥当性の検証も今後の検討課題である。

(2) これまでの調查の範囲に含まれない強い降雨の割 合が大きく, その分の寄与が, とくに変動分として大き い事がわかった。これらの強い降雨の調査は安全面など から実施が難しいことが多い。しかし結果に与える影響 が大きいことを考えると，リモートによる観測などを利 用し, 実証的な情報を集めていくことが今後重要である と考えられる。また積雪地域については積雪や融雪の影 響を別途考える必要がある。

(3) 本研究では, 対象地域で調查された EMC, 対象イ ベントの流量, 年間総流量から年間負荷量を推定する場 合，年間のおよそ半分のイベントでのサンプリングを実 施したとしても，95\%信頼区間で 2 倍程度のばらつきが 生じることが示唆された。このことは, 原単位を精緻に 測定するためには, きわめて重厚な調査デー夕を要する ことを意味する。重厚な調査デー夕の獲得ならびにモデ ル化による推定手法の確立を進めると共に, 変動の大き さを考慮した上で害態把握や対策立案といった評価を実 施することが求められる。

本研究では得られた DB に基づき解析を実施した。解 析実施に先立ち降雨ごとの EMC を基本的な集約情報と 見なし，一般に原単位として用いられる「単位面積当あ たりの年間負荷量」（表 7) を導出した。単位面積あたり の年間負荷量は, 例えば流域の状況とともに変化するこ とが想定される。現在, 技術的, 社会的な要請としては, 対策のための技術や制度によってどのように污濁流出負 荷が削減され，管理できるかという点が重要になってい る。これらの要請に応えるためには, 本研究で害施した $\mathrm{EMC}$ に影響を及ぼす因子の解明に加えて, 多様な地表 面種ごとの原単位の調査といった調査, 物理モデルの活 用などが求められる。

\section{謝 辞}

本研究の成果は国土交通省下水道技術研究開発 (GAIA プロジェクト) によるものである。記して感謝の 意を表する。また本研究で用いたデータベースは環境省 環境研究総合推進費（RFb-11T1）の成果に基づくもの である。本データベースの収集に当たっては多くの自治 体関係者のご協力をいただいた。またその整理は多くの 研究者のご努力によるものである。論文作成において広
島大学理学研究科の藤越康祝教授ならび若木宏文教授に 統計解析実施に関するアドバイスをいただいた。記して 感謝の意を表する。

\section{付録：補足資料}

補足資料は下記より閲覧可能である。

https://www.jstage.jst.go.jp/browse/jswe/-char/ja/

(原稿受付 2016 年 3 月 30 日)

(原稿受理 2017 年 1 月 19 日)

\section{参 考 文 献}

1 ) 和田桂子, 藤井滋穂, 2006. 雨天時における路面排水の水質特 性求よび污濁負荷の流出挙動に関する研究. 水環境学会誌 29 (11), 699-704.

2 ）新矢将尚，小西孝明，宮西弘樹，石川宗孝，2002. 高速道路排 水における污濁負荷の流出特性. 用水と廃水 44(3), 207-213.

3 ) 尾崎則篤, 鴈田孝広, 福島武彦, 山口登志子, 2000. 市街地一 の多環芳香族炭化水素類の地表面堆積とその降雨時流出. 環境工 学研究論文集 37, 403-409.

4 ) 熊谷香, 内藤剛, 2007. 有明海福岡県地先への栄養塩供給量の 動向. 福岡県水産海洋技術センター研究報告 17, 73-80.

5 ) 反田實, 原田和弘, 2012. 瀬戸内海東部（播磨灘）の栄養塩環 境と漁業. 海洋と生物 34(2), 132-141.

6 ）環境省, 2015. 瀬戸内海環境保全特別措置法の一部改正. URL. http://www.env.go.jp/water/heisa/setonaikai_law_rev/ kaiseiho-zenbun.pdf (2016 年 1 月時点).

7 ) 国土交通省水管理・国土保全局下水道部, 2015. 下水放流水に 含まれる栄養塩類の能動的管理のための運転方法に係る手順書 (案), p. 113 .

8) SWAT Developer's Google group, 2016. SWAT (Soil and Water Assessment Tool). URL. http://swat.tamu.edu/ (2016 年 11 月時点).

9 ）国土交通省水管理 - 国土保全局下水道部，2015. 流域別下水道 整備総合計画調査 指針と解説. URL. http://www.mlit.go.jp/ mizukokudo/sewerage/mizukokudo_sewerage_tk_000311.html (2016 年 11 月時点).

10）環境省 水 ·大気環境局水環境課，2014. 非特定污染源対策の 推進に係るガイドライン (第二版). URL. http://www.env.go.jp/ water/kosyou/hitokutei/index.html (2016 年 11 月時点).

11）千葉県, 2003 . 平成 14 年度環境省委託業務結果報告書 非特定 污染源負荷削減計画策定調查.

12）建設省土木研究所下水道研究室, 1980. 分流式下水道からの雨 水流出水に関するデータベース. 土木研究所資料 第 1549 号.

13）建設省土木研究所下水道部水質研究室, 1989. 污濁負荷の原単 位に関する調查報告書 (1)。土木研究所資料 第 2766 号.

14）松本順一郎, 1984. 非特定污染源による污染防止対策調査報告 書 - 文献調查 - . 昭和 59 年度環境庁委託業務結果報告書. 社団 法人水質污濁研究協会, 東京.

15）古米弘明, 2012. 非特定污染源からの流出負荷量の推計手法に 関する研究. 平成 23 年度 環境省環境研究総合推進費成果報告書 $(\mathrm{RFb}-11 \mathrm{~T} 1)$. 社団法人日本水環境学会, 東京.

16）日本水環境学会ノンポイント污染研究委員会, 2016. 非特定污 染源からの流出負荷量の推計手法に関する研究. URL. http:// jswe-nonpoint.com/h23suishin/index.html (2016 年 11 月時点).

17) Sartor, J.D., Boyd, G.B., 1972. Water pollution aspects of street surface contaminants. USEPA, EPA-R2-72-081.

18）中村栄一, 1993. 雨水流出水による污濁負荷の流出特性. 下水 道協会誌論文集 $30(364), 1-13$.

19）村上道夫, 古米弘明, 中島典之, Jinadasa Haltota K.P.K., Aryal Rupak K., 2008. 降雨特性の異なる 66 降雨における雨水浸透施 設からの浸透量の評価. 用水と廃水 50(3), 227-233.

20）沼山翔，土屋十图，2005. 日本の気候区分の再評価に関する研 究. 第 18 回 (2005 年度) 水文・水資源学会総会 - 研究発表会, セッション ID：P-89. DOI: 10.11520/jshwr.18.0.162.0

21）小泉和也, 加藤央之, 2012. 気候要素の変動パターンに基づく 日本の気候区分. 日本大学文理学部自然科学研究所研究紀要 47 , 185-197. 
[論 文 要 旨]

雨天時に抢ける市街地流出を調査している報告書, 論文等の文献を収集し（1968～2011 年），一降雨を単 位とした市街地の污濁負荷（BOD, COD, SS, TN, TP）の負荷流出データベース（DB）をまとめ，一降雨の 流量加重平均濃度（EMC）の分布を明らかにした。続いて降雨条件, 地理的状況が EMC に及ぼす影響を回 帰式で予測し, 日本全国の 4 地点での降雨条件を与えた際の年間流出負荷の予測值とその変動係数を導出し た。その予測に基づき，信頼性のある流出負荷量を算出するためにどの程度の降雨の採水頻度が必要になる のかをシミュレーションにより検討した。95\% 信頼区間を 2 倍以内程度の誤差とする場合, 水質項目によっ ては年間の全降雨イベントのうち半分程度を採水する必要があることを明らかにした。

キーワード：EMC（event mean concentration）；有機物；SS；栄養塩類；原単位 